\title{
OPEN The emergency discharge of sewage to the Bay of Gdańsk as a source of bacterial enrichment in coastal air
}

\author{
Małgorzata Michalska ${ }^{1,4} \llbracket$, Katarzyna Zorena $\mathbb{1}^{1,4}$, Roman Marks $\mathbb{1}^{2}$ \& Piotr Wąż $\mathbb{1}^{3}$
}

The purpose of this research was to study the presence of potential pathogenic bacteria in the seawater and air in five coastal towns (Hel, Puck, Gdynia, Sopot, Gdańsk-Brzeźno) as well as the enrichment of bacteria from the seawater into the coastal air after an emergency discharge of sewage into the Bay of Gdańsk. A total of 594 samples of air and seawater were collected in the coastal zone between spring and summer (between 2014 and 2018). Air samples were collected using the impact method with a SAS Super ISO 100. The multivariate analysis, conducted using contingency tables, showed a statistically significant variation between the concentration of coliforms, psychrophilic and mesophilic bacteria in the seawater microlayer and air in 2018, after an emergency discharge of sewage into the Bay of Gdańsk, compared to 2014-2017. Moreover, we detected a marine aerosol enrichment in psychrophilic, mesophilic bacteria, coliforms and Escherichia coli. We also showed a statistically significant relationship between the total concentration of bacteria and humidity, air temperature, speed and wind direction. This increased concentration of bacteria in the seawater and coastal air, and the high factor of air enrichment with bacteria maybe associated with the emergency discharge of wastewater into the Bay of Gdańsk. Therefore, it is suggested that in the event of a malfunction of a sewage treatment plant, as well as after floods or sudden rainfall, the public should be informed about the sanitary and epidemiological status of the coastal waters and be recommended to limit their use of coastal leisure areas.

Physicochemical and microbiological pollution of coastal waters is an important issue in low and middle income countries (LMICs) ${ }^{1}$. Coastal aerosols can have a major influence on the planet's ecology and climate, and have been associated with a suite of human health problems ${ }^{2-5}$. The presence of bacteria, mould spores and their metabolic products (e.g. endotoxins or mycotoxins) in sea spray aerosols (SSA) may be one of the main factors influencing human infections ${ }^{6,7}$. The latest research shows that seawater pollution with potentially pathogenic bacteria belonging to faecal streptococci (Enterococci), coliforms or Escherichia coli is a significant threat to human health ${ }^{7-10}$. The bacteria and components of their cell walls (e.g. D-glucans) can cause gastrointestinal and respiratory tract disorders or skin allergies and, as a consequence, contribute to many illnesses ${ }^{11-16}$. Faecal coliforms live primarily in the human digestive tract. Their presence in the natural environment is a result of municipal wastewater discharges and runoffs from urban and agricultural areas into surface waters ${ }^{17-22}$. Many years of research by ourselves and other researchers have showed that despite a very high reduction in the concentration of bacteria during the treatment process, treated sewage still contains more than $10^{4} \mathrm{CFU} / 100 \mathrm{ml}$ of faecal coliforms ${ }^{17,23-25}$. It is known thatheavy rainfall or floods contribute to a higher concentration of faecal bacteria in coastal seawaters ${ }^{26-28}$. Another problem are sewage pumping station failures. For example, due to a malfunction at the Mishref Pumping Station (Kuwait), around 150,000 $\mathrm{m}^{3} /$ day of raw sewage was being discharged directly into the bay for a period of 3 years (2009-2012). This led to a bacteriological contamination of a coastal section of about $20 \mathrm{~km}$ in the Kuwait Bay waters ${ }^{29}$.

\footnotetext{
${ }^{1}$ Department of Immunobiology and Environment Microbiology, Faculty of Health Sciences with Institute of Maritime and Tropical Medicine Medical University of Gdańsk, ul. Dębinki 7, 80-211 Gdańsk, Poland. ${ }^{2}$ Institute of Marine and Environmental Sciences, University of Szczecin, ul. Mickiewicza 16, 70-383 Szczecin, Poland. ${ }^{3}$ Department of Nuclear Medicine, Faculty of Health Sciences with Institute of Maritime and Tropical Medicine, Medical University of Gdańsk, ul. Dębinki 7, 80-211 Gdańsk, Poland. ${ }^{4}$ These authors contributed equally: Małgorzata Michalska and Katarzyna Zorena. ${ }^{\circledR}$ email: malgorzata.michalska@gumed.edu.pl
} 


\begin{tabular}{|c|c|c|c|c|c|c|}
\hline & $\begin{array}{l}\text { Psychrophilic bacteria } \\
\text { (CFU/1 ml) }\end{array}$ & $\begin{array}{l}\text { Psychrophilic bacteria } \\
\text { (CFU/1 ml) }\end{array}$ & Fold change & $\begin{array}{l}\text { Mesophilic bacteria } \\
\text { (CFU/1 ml) }\end{array}$ & $\begin{array}{l}\text { Mesophilic bacteria } \\
\text { (CFU/1 ml) }\end{array}$ & Fold change \\
\hline Location & $2018^{*}$ & 2014-2017 & 2018 vs $2014-2017$ & $2018^{*}$ & 2014-2017 & 2018 vs 2014-2017 \\
\hline Hel & $3.34 \times 10^{5} \pm 3.115 \times 10^{5}$ & $\begin{array}{l}1.019 \times 10^{4} \pm 1.351 \times 10^{4} ; \\
6 \times 10^{3}\left(200-4.8 \times 10^{3}\right)^{\mathrm{b}}\end{array}$ & 33 & $\begin{array}{l}3.115 \times 10^{5} \pm 3.507 \times 10^{5} \\
3.9 \times 10^{5}\left(4 \times 10^{3}-6.3 \times 10^{5}\right)^{b}\end{array}$ & $\begin{array}{l}2.715 \times 10^{3} \pm 2.719 \times 10^{3} ; \\
1.8 \times 10^{3}\left(100-8.9 \times 10^{3}\right)^{\mathrm{b}}\end{array}$ & 114 \\
\hline Puck & $5.433 \times 10^{3} \pm 8.62 \times 10^{2}$ & $4.218 \times 10^{3} \pm 1.624 \times 10^{3}$ & 1,3 & $3.967 \times 10^{3} \pm 6.11 \times 10^{2}$ & $2.2 \times 10^{3} \pm 2.1 \times 10^{3}$ & 2 \\
\hline Gdynia & $1.508 \times 10^{4} \pm 1.326 \times 10^{3}$ & $5.232 \times 10^{3} \pm 1.315 \times 10^{3}$ & 3 & $7.008 \times 10^{3} \pm 4.195 \times 10^{3}$ & $3.110 \times 10^{3} \pm 1.316 \times 10^{3}$ & 2 \\
\hline Sopot & $1.123 \times 10^{4} \pm 6.621 \times 10^{3}$ & $4.617 \times 10^{3} \pm 1.213 \times 10^{3}$ & 2,4 & $9.146 \times 10^{3} \pm 5.606 \times 10^{3}$ & $2.073 \times 10^{3} \pm 8.88 \times 10^{2}$ & 4,4 \\
\hline Gd.-Brzeźno a & $\begin{array}{l}2.411 \times 10^{4} \pm 4.731 \times 10^{4} \\
1 \times 10^{4}\left(4.5 \times 10^{3}-1.5 \times 10^{5}\right)^{b}\end{array}$ & $4.292 \times 10^{3} \pm 9.95 \times 10^{2}$ & 6 & $\begin{array}{l}1.585 \times 10^{4} \pm 2.423 \times 10^{4} \\
1 \times 10^{4}\left(4.2 \times 10^{3}-8 \times 10^{4}\right)^{b}\end{array}$ & $3.787 \times 10^{3} \pm 5.85 \times 10^{2}$ & 4,2 \\
\hline p-value ${ }^{c}$ & \multicolumn{2}{|l|}{0.025} & & \multicolumn{2}{|l|}{0.025} & \\
\hline
\end{tabular}

Table 1. The mean and standard deviation of concentration of psychrophilic and mesophilic bacteria (CFU/1 ml) in sea-surface microlayer samples collected in the Bay of Gdańsk in 2018 versus 2014-2017. ${ }^{\mathrm{a}} \mathrm{Gd}$.Brzeźno-it is an abbreviation of the town name Gdańsk-Brzeźno, bin case of a higher standard deviation than the mean, the median and range (min-max) was calculated, ${ }^{c}$ Friedman test, $\alpha-0.05$, ${ }^{\star}$ The results marked in grey colour have been published in preliminary study ${ }^{36}$.

The quality of seawater is assessed not only by examining the number of intestinal bacteria, but also the total number of psychrophilic and mesophilic bacteria, Pseudomonas aeruginosa and Staphylococcus aureus ${ }^{30-34}$. For example, the number of mesophilic bacteria indicates the presence of pathogenic and potentially pathogenic microorganisms in the water. On the other hand, the number of psychrophilic bacteria indicates the organic matter content in the water ${ }^{30,31}$. P. aeruginosa is able to survive during long periods without nutrients in a dormant state, and significantly longer than the two other bacterial pathogens, E. coli and S. aureus ${ }^{32-34}$. S. aureus, on the other hand, is an opportunistic pathogen and is known to survive at higher salinity ${ }^{35}$. From May 15 th to 18th (for 3 days) 2018, there were emergency discharges of raw sewage into the Motława River, which then went into the Bay of Gdańsk. As a result, $2300 \mathrm{~m}^{3}$ of untreated municipal wastewater were discharged into the Bay of Gdańsk per hour.

In our preliminary study, we presented the results about the increase of potentially pathogenic mesophilic bacteria in the seawater and coastal air in 2018 after an emergency discharge of raw sewage from the Gdańsk-Wschód wastewater plant into the Bay of Gdańsk ${ }^{36}$. The aim of the present study was to compare the bacterial concentration in seawater and air in five coastal towns before (2014-2017) and after (2018) an emergency discharge of sewage into the Bay of Gdańsk. Moreover, we assessed the enrichment of bacteria of the coastal air, over the Bay of Gdańsk, from the surface microlayer (SML) by the eruption of rising bubbles, based on the data obtained in Hel, Puck, Gdynia, Sopot and Gdańsk-Brzeźno.

The SML is a unique biological, physical and chemical environment at the interface between the atmosphere and the hydrosphere. The SML contains elevated concentrations of heterotrophic and autotrophic microorganisms including bacteria, cyanobacteria, flagellates and alga $\mathrm{e}^{38}$. These microorganisms impact air quality through transmission of allergens and pathogens and play a key role in global biogeochemical and climate regulation processes $^{1,4,5,37,38}$. Very few studies have investigated the enrichment of air with microorganisms after storms and heavy rains ${ }^{39}$, and to our knowledge, there are currently no studies linking emergency discharges of raw sewage to microbial air enrichment. Therefore, the failure of the sewage pumping station in the Bay of Gdańsk offered a unique opportunity to investigate the effects of sewage discharges on bacterial enrichment of coastal air.

\section{Results}

Analysis of bacteria in the sea-surface microlayer in the 5 coastal towns of the Bay of Gdańsk in 2018 and during 2014-2017. The concentration of psychrophilic and mesophilic bacteria in the seasurface microlayer samples was higher in 2018 than in 2014-2017 at the seaside towns of Hel, Gdynia, Sopot and Gdańsk-Brzeźno. Using the non-parametric Friedman rank sum test, we demonstrated a statistically significant difference between the mean concentration of psychrophilic and mesophilic bacteria in the 5 seaside towns before and after the discharge $\left(\chi^{2}=5, \mathrm{df}=1, \mathrm{p}=0.025\right)$. The mean, median, and standard deviation values for the concentration of psychrophilic and mesophilic bacteria are presented in Table 1.

In 2018 the concentration of coliforms in the SML collected from the Bay of Gdańsk, in Puck, Sopot and Gdańsk-Brzeźno, was higher compared to $2014-2017$ but not statistically significant $\left(\chi^{2}=1.8, \mathrm{df}=1 \mathrm{p}=0.18\right)$. The concentration of E. coli in SML samples was higher in 2018 than in 2014-2017 at the Puck and Gdańsk-Brzeźno seaside towns, but nostatistical significance was found $\left(\chi^{2}=0.2, \mathrm{df}=1, \mathrm{p}=0.655\right)$ (Table 2).

The concentrations of $P$. aeruginosa and S. aureus detected in the SML were higher in 2018 than in 2014-2017, in Hel, Sopot and Gdańsk-Brzeźno, but not statistically significant $\left(\chi^{2}=1, \mathrm{df}=1, \mathrm{p}=0.317\right)$. The results are presented in Table 3.

The relationship between the concentration of bacteria detected in the SML samples collected over the Bay of Gdańsk in the 5 coastal towns in 2018 and the 2014-2017 period. A Pearson chi-squared test of independence showed that during 2014-2017 in Hel, there was a lower concentration of psychrophilic and mesophilic bacteria than expected. In 2018, on the other hand, a higher concentration of psy- 


\begin{tabular}{|c|c|c|c|c|c|c|}
\hline \multirow[b]{2}{*}{ Location } & $\begin{array}{l}\text { Coliform bacteria } \\
(\mathrm{CFU} / 100 \mathrm{ml})\end{array}$ & $\begin{array}{l}\text { Coliform bacteria } \\
\text { (CFU/100 ml) }\end{array}$ & Fold change & E. coli $(\mathrm{CFU} / 100 \mathrm{ml})$ & E. coli $(\mathrm{CFU} / 100 \mathrm{ml})$ & Fold change \\
\hline & $2018^{*}$ & 2014-2017 & 2018 vs $2014-2017$ & $2018^{*}$ & 2014-2017 & 2018 vs $2014-2017$ \\
\hline Hel & $\begin{array}{l}2.805 \times 10^{3} \pm 2.8 \times 10^{3} \\
2.31 \times 10^{3}\left(4 \times 10^{2}-6.2 \times 10^{3}\right)^{\mathrm{b}}\end{array}$ & $3.587 \times 10^{3} \pm 2.497 \times 10^{3}$ & - & $\begin{array}{l}2.06 \times 10^{2} \pm 3.96 \times 10^{2} \\
12\left(0-8 \times 10^{2}\right)^{\mathrm{b}}\end{array}$ & $\begin{array}{l}4.46 \times 10^{2} \pm 5.42 \times 10^{2} \\
2.3 \times 10^{2}\left(0-1.8 \times 10^{3}\right)^{b}\end{array}$ & - \\
\hline Puck & $1.157 \times 10^{3} \pm 1.69 \times 10^{2}$ & $3.73 \times 10^{2} \pm 2.97 \times 10^{2}$ & 3 & $2.23 \times 10^{2} \pm 1.2 \times 10^{1}$ & $1.9 \times 10^{1} \pm 8$ & 11 \\
\hline Gdynia & $2.5 \times 10^{3} \pm 3.81 \times 10^{2}$ & \begin{tabular}{|l|}
$1.612 \times 10^{3} \pm 9.74 \times 10^{2}$ \\
$9.74 \times 10^{2}\left(2.3 \times 10^{2}-2.3 \times 10^{3}\right)^{b}$
\end{tabular} & 1,5 & $10 \pm 7$ & \begin{tabular}{|l|}
$5.61 \times 10^{2} \pm 9.78 \times 10^{2}$ \\
$9.78 \times 10^{2}\left(23-2.3 \times 10^{3}\right)^{\mathrm{b}}$
\end{tabular} & - \\
\hline Sopot & $\begin{array}{l}3.280 \times 10^{4} \pm 8.006 \times 10^{4} \\
1.265 \times 10^{3}\left(2.3 \times 10^{2}-2.3 \times 10^{5}\right)^{b}\end{array}$ & $5.7 \times 10^{2} \pm 8.7 \times 10^{1}$ & 57 & $\begin{array}{l}1.39 \times 10^{2} \pm 1.79 \times 10^{2} \\
72\left(0-5.1 \times 10^{2}\right)^{\mathrm{b}}\end{array}$ & $3.6 \times 10^{2} \pm 2.25 \times 10^{2}$ & - \\
\hline Gd.-Brzeźno a & $\begin{array}{l}5.439 \times 10^{3} \pm 7.452 \times 10^{3} \\
2.3 \times 10^{3}\left(2.3 \times 10^{2}-2.4 \times 10^{4}\right)^{\mathrm{b}}\end{array}$ & $2.13 \times 10^{2} \pm 1.5 \times 10^{1}$ & 26 & $\begin{array}{l}2.11 \times 10^{2} \pm 2.28 \times 10^{2} \\
1.3 \times 10^{2}\left(0-7 \times 10^{2}\right)^{\mathrm{b}}\end{array}$ & $1.89 \times 10^{2} \pm 3.6 \times 10^{1}$ & 1 \\
\hline $\mathrm{p}$-value $\mathrm{c}^{\mathrm{C}}$ & 0.180 & & & 0.655 & & \\
\hline
\end{tabular}

Table 2. The mean and standard deviation of concentration of coliforms and E. coli (CFU/100 ml) in seasurface microlayer samples collected in the Bay of Gdansk in 2018 versus 2014-2017. ${ }^{\mathrm{a}} \mathrm{Gd}$.-Brzeźno-it is an abbreviation of the town name Gdańsk-Brzeźno, bin case of a higher standard deviation than the mean, the median and range ( $\min -\max$ ) was calculated, ${ }^{c}$ Friedman test, $\alpha-0.05,{ }^{\star}$ The results marked in grey colour have been published in preliminary study ${ }^{36}$.

\begin{tabular}{|c|c|c|c|c|c|c|}
\hline \multirow[b]{2}{*}{ Location } & P. aeruginosa $(\mathrm{CFU} / 100 \mathrm{ml})$ & P. aeruginosa $(\mathrm{CFU} / 100 \mathrm{ml})$ & Fold change & S. aureus $(\mathrm{CFU} / 100 \mathrm{ml})$ & S. aureus (CFU/100 ml) & Fold change \\
\hline & 2018 & 2014-2017 & 2018 vs $2014-2017$ & 2018 & 2014-2017 & 2018 vs $2014-2017$ \\
\hline Hel & $\begin{array}{l}1.7 \times 10^{3} \pm 2 \times 10^{3} \\
16\left(0-3.6 \times 10^{3}\right)^{\mathrm{b}}\end{array}$ & $\begin{array}{l}1.31 \times 10^{2} \pm 3.01 \times 10^{2} \\
0\left(0-9 \times 10^{2}\right)^{\mathrm{b}}\end{array}$ & 13 & $\begin{array}{l}1.5 \times 10^{2} \pm 3 \times 10^{2} \\
0\left(0-6 \times 10^{2}\right)^{\mathrm{b}}\end{array}$ & $\begin{array}{l}1.5 \times 10^{1} \pm 5.5 \times 10^{1} \\
0\left(0-2 \times 10^{2}\right)^{\mathrm{b}}\end{array}$ & 10 \\
\hline Puck & 0.00 & 0.00 & - & $\begin{array}{l}1.67 \times 10^{2} \pm 2.89 \times 10^{2} \\
0\left(0-5 \times 10^{2}\right)^{\mathrm{b}}\end{array}$ & $1.5 \times 10^{2} \pm 1.29 \times 10^{2}$ & 1 \\
\hline Gdynia & 0.00 & $\begin{array}{l}1 \times 10^{2} \pm 2.24 \times 10^{2} \\
0\left(0-5 \times 10^{2}\right)^{\mathrm{b}}\end{array}$ & - & $\begin{array}{l}1.2 \times 10^{2} \pm 1.3 \times 10^{2} \\
1 \times 10^{2}\left(0-3 \times 10^{2}\right)^{\mathrm{b}}\end{array}$ & $\begin{array}{l}6 \times 10^{1} \pm 8.9 \times 10^{1} \\
0\left(0-2 \times 10^{2}\right)^{\mathrm{b}}\end{array}$ & 20 \\
\hline Sopot & $\begin{array}{l}4.75 \times 10^{2} \pm 7.65 \times 10^{2} \\
0\left(0-2.1 \times 10^{3}\right)\end{array}$ & 0.00 & 5 & $\begin{array}{l}1.63 \times 10^{2} \pm 2.26 \times 10^{2} \\
0\left(0-5 \times 10^{2}\right)^{\mathrm{b}}\end{array}$ & $\begin{array}{l}1.33 \times 10^{2} \pm 2.32 \times 10^{2} \\
0\left(0-4 \times 10^{2}\right)^{\mathrm{b}}\end{array}$ & 1 \\
\hline Gd.-Brzeźnoa & $\begin{array}{l}4.89 \times 10^{2} \pm 8.01 \times 10^{2} \\
0\left(0-2.2 \times 10^{3}\right)^{\mathrm{b}}\end{array}$ & 0.00 & 5 & $\begin{array}{l}1.67 \times 10^{2} \pm 3.08 \times 10^{2} \\
0\left(0-8 \times 10^{2}\right)^{\mathrm{b}}\end{array}$ & $\begin{array}{l}1 \times 10^{2} \pm 1.73 \times 10^{2} \\
0\left(0-3 \times 10^{2}\right)^{\mathrm{b}}\end{array}$ & 2 \\
\hline $\mathrm{p}$-value ${ }^{\mathrm{c}}$ & 0.317 & & & 0.317 & & \\
\hline
\end{tabular}

Table 3. The mean and standard deviation of concentration of $P$. aeruginosa and $S$. aureus (CFU/100 ml) in sea-surface microlayer water collected from the Bay of Gdansk in 2018 versus 2014--2017. ${ }^{\mathrm{a}} \mathrm{Gd}$.-Brzeźno-it is an abbreviation of the town name Gdańsk-Brzeźno, bin case of a higher standard deviation than the mean, the median and range (min-max) was calculated, ${ }^{c}$ Friedman test, $\alpha-0.05$.

chrophilic $\left(\chi^{2}=55,643, \mathrm{df}=4, \mathrm{p}=<2.22 \times 10^{-16}\right)$ and mesophilic bacteria $\left(\chi^{2}=63,928, \mathrm{df}=4, \mathrm{p}=<2.22 \times 10^{-16}\right)$ was detected in Hel compared to the expected value according to the use of the independence test (Fig. 1A, B).

In 2018, in Sopot and Gdańsk-Brzeźno, a higher than expected concentration of coliforms was recorded, while in 2014-2017 it was lower. The result was statistically significant $\left(\chi^{2}=18,656, \mathrm{df}=4, \mathrm{p}=<2.22 \times 10^{-16}\right)$. Also, in 2018, in Puck and Gdańsk-Brzeźno, the concentration of E. coli was higher than expected, while in 2014-2017 it was lower $\left(\chi^{2}=709.96, \mathrm{df}=4, \mathrm{p}=<2.22 \times 10^{-16}\right)$ (Fig. $\left.1 \mathrm{C}, \mathrm{D}\right)$.

The results during 2014-2017 and in 2018 showed that in Hel, Sopot and Gdańsk-Brzeźno the mean concentration of $P$. aeruginos $a$ and $S$. aureus was very close to the expected value, according to the use of the independence test. The result was statistically significant for the mean concentration of $P$. aeruginos $a\left(\chi^{2}=12.7, \mathrm{df}=4\right.$, $\mathrm{p}=0.015)$. However, no statistical significance was demonstrated when comparing the average concentration of S. aureus bacteria in the water in $2014-2017$ vs $2018\left(\chi^{2}=0.778, \mathrm{df}=4, \mathrm{p}=0.941\right)$ (Fig. 1E, F).

Analysis of bacteria in the air in the 5 coastal towns of the Bay of Gdańsk in 2018 compared to 2014-2017. The concentrations of psychrophilic and mesophilic bacteria in the sea spray aerosol (SSA), from Gdynia, Sopot and Gdańsk-Brzeźno, were significantly higher in 2018 compared to 2014-2017. The nonparametric Friedman rank sum test showed a statistically significant difference between the mean concentrations of psychrophilic and mesophilic bacteria in Hel, Puck, Gdynia, Sopot and Gdańsk-Brzeźno in 2014-2017 and those in $2018\left(\chi^{2}=5, \mathrm{df}=1, \mathrm{p}=0.025\right)$. The results are presented in Table 4 .

The concentration of coliforms in the sea spray aerosol (SSA) samples after an emergency discharge of raw sewagewas higher in 2018 than in 2014-2017 at the seaside towns of Hel, Gdynia, Sopot and Gdańsk-Brzeźno. The non-parametric Friedman rank sum test showed that the results were statistically significant $\left(\chi^{2}=5, \mathrm{df}=1\right.$, $\mathrm{p}=0.025)$.

Moreover, at the coastal towns of Hel, Puck, Sopot and Gdańsk-Brzeźno statistically significant differences of concentrations of E. coli, in the SSA samples from 2018 compared to $2014-2017$, were detected $(\chi 2=4, \mathrm{df}=1$, 

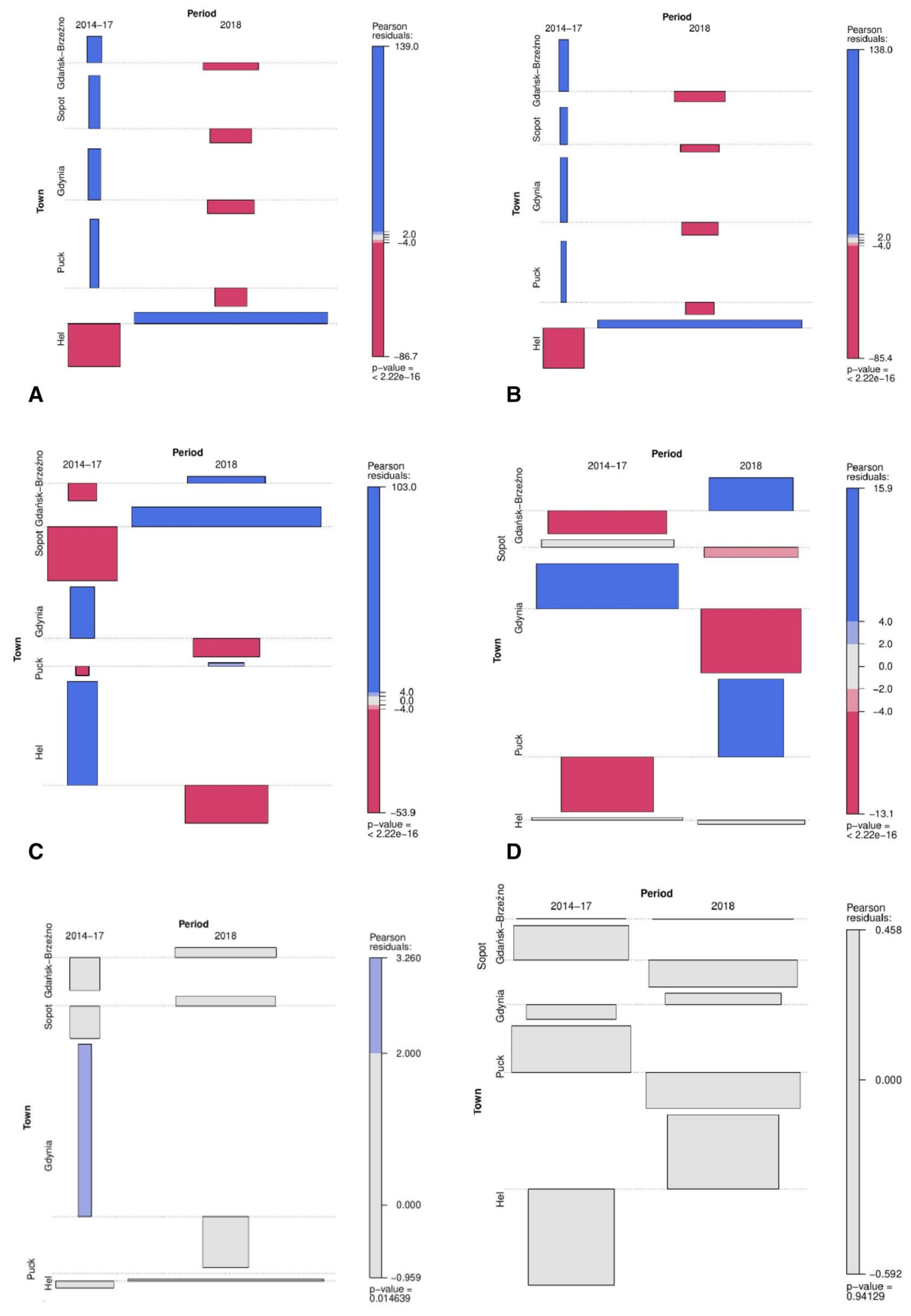

E

$\mathbf{F}$

Figure 1. The association of the contingency table with the mean quantity of psychrophilic (A) and mesophilic bacteria (B), coliform (C) and E. coli (D) bacteria, P. aeruginosa $(\mathbf{E})$ and S.aureus $(\mathbf{F})$ bacteria detected in the SSA samples collected from the Bay of Gdańsk in Hel, Puck, Gdynia, Sopot and Gdańsk-Brzeźno and the time period for the sample collection (2014-2017 and 2018). The blue colour indicates that the observed value is higher than expected if the data was random. The red colour specifies that the observed value is expected value and the grey colour indicates that the observed value is close to the expected. 


\begin{tabular}{|c|c|c|c|c|c|c|}
\hline \multirow[b]{2}{*}{ Location } & $\begin{array}{l}\text { Psychrophilic bacteria } \\
\left(\mathrm{CFU} / \mathrm{m}^{3}\right)\end{array}$ & $\begin{array}{l}\text { Psychrophilic bacteria } \\
\left(\mathrm{CFU} / \mathbf{m}^{3}\right)\end{array}$ & Fold change & $\begin{array}{l}\text { Mesophilic bacteria }(\mathrm{CFU} / \mathrm{a} \\
\left.\mathbf{m}^{3}\right)\end{array}$ & $\begin{array}{l}\text { Mesophilic bacteria (CFU/ } \\
\left.\mathbf{m}^{3}\right)\end{array}$ & Fold change \\
\hline & $2018^{*}$ & 2014-2017 & 2018 vs $2014-2017$ & $2018^{*}$ & 2014-2017 & 2018 vs $2014-2017$ \\
\hline Hel & $1.645 \times 10^{3} \pm 1.273 \times 10^{3}$ & $1.049 \times 10^{3} \pm 6.40 \times 10^{2}$ & 2 & $1.51 \times 10^{3} \pm 1.101 \times 10^{3}$ & $9.00 \times 10^{2} \pm 6.02 \times 10^{2}$ & 2 \\
\hline Puck & $1.021 \times 10^{3} \pm 1.95 \times 10^{2}$ & $9.34 \times 10^{2} \pm 1.85 \times 10^{2}$ & 1 & $5.88 \times 10^{2} \pm 1.91 \times 10^{2}$ & $6.07 \times 10^{2} \pm 2.78 \times 10^{2}$ & - \\
\hline Gdynia & $8.11 \times 10^{2} \pm 1.65 \times 10^{2}$ & $1.67 \times 10^{2} \pm 1.17 \times 10^{2}$ & 5 & $7.02 \times 10^{2} \pm 1.63 \times 10^{2}$ & $\begin{array}{l}1.02 \times 10^{2} \pm 1.32 \times 10^{2} \\
28\left(12-3 \times 10^{2}\right)^{\mathrm{b}}\end{array}$ & 7 \\
\hline Sopot & $\begin{array}{l}5.06 \times 10^{2} \pm 1.165 \times 10^{3} \\
1.14 \times 10^{2}\left(32-3.386 \times 10^{3}\right)^{b}\end{array}$ & $1.27 \times 10^{2} \pm 5.6 \times 10^{1}$ & 4 & $\begin{array}{l}4.86 \times 10^{2} \pm 1.141 \times 10^{3} \\
9.5 \times 10^{1} \\
\left(2.7 \times 10^{1}-3.307 \times 10^{3}\right)^{\mathrm{b}}\end{array}$ & $7.8 \times 10^{1} \pm 4.8 \times 10^{1}$ & 6 \\
\hline Gd.-Brzeźno ${ }^{a}$ & $\begin{array}{l}2.287 \times 10^{3} \pm 2.677 \times 10^{3} ; \\
4.89 \times 10^{2} \\
\left(5.5 \times 10^{1}-5.774 \times 10^{3}\right)^{\mathrm{b}}\end{array}$ & $\begin{array}{l}4.14 \times 10^{2} \pm 4.66 \times 10^{2} \\
2.08 \times 10^{1} \\
\left(8.7 \times 10^{1}-9.47 \times 10^{2}\right)^{\mathrm{b}}\end{array}$ & 5,5 & $\begin{array}{l}1.832 \times 10^{3} \pm 2.104 \times 10^{3} \\
3.94 \times 10^{2}\left(16-4.856 \times 10^{3}\right)^{b}\end{array}$ & $\begin{array}{l}3.76 \times 10^{2} \pm 4.91 \times 10^{2} \\
1.04 \times 10^{2}(8.1 \times 101- \\
\left.9.43 \times 10^{2}\right)^{\mathrm{b}}\end{array}$ & 5 \\
\hline p-value ${ }^{c}$ & 0.025 & & & 0.025 & & \\
\hline
\end{tabular}

Table 4. The mean and standard deviation of concentration of psychrophilic and mesophilic bacteria (CFU/ $\mathrm{m}^{3}$ ) in air over the Bay of Gdańsk in 2018 versus 2014-2017. ${ }^{\mathrm{a}} \mathrm{Gd}$.-Brzeźno-it is an abbreviation of the town name Gdańsk-Brzeźno, bin case of a higher standard deviation than the mean, the median and range (min-max) was calculated, ${ }^{c}$ Friedman test, $\alpha-0.05,{ }^{\star}$ The results marked in grey colour have been published in preliminary study ${ }^{36}$.

\begin{tabular}{|c|c|c|c|c|c|c|}
\hline & $\begin{array}{l}\text { Coliform bacteria } \\
\left(\mathrm{CFU} / \mathrm{m}^{3}\right)\end{array}$ & $\begin{array}{l}\text { Coliform bacteria } \\
\left(\mathrm{CFU} / \mathrm{m}^{3}\right)\end{array}$ & Fold change & E. coli $\left(\mathrm{CFU} / \mathrm{m}^{3}\right)$ & $\begin{array}{l}\text { E. coli (CFU/ } \\
\left.\mathrm{m}^{3}\right)\end{array}$ & Fold change \\
\hline Location & $2018^{*}$ & 2014-2017 & \begin{tabular}{|l}
2018 vs \\
$2014-2017$
\end{tabular} & $2018^{*}$ & 2014-2017 & $\begin{array}{l}2018 \text { vs } \\
2014-2017\end{array}$ \\
\hline Hel & $\begin{array}{l}1.98 \times 10^{2} \pm 2.61 \times 10^{2} \\
1.2 \times 10^{2}\left(0-5.1 \times 10^{1}\right)^{\mathrm{b}}\end{array}$ & $\begin{array}{l}2 \pm 3 \\
2\left(0-1 \times 10^{1}\right)^{b}\end{array}$ & 99 & \begin{tabular}{|l|}
$2 \pm 4$ \\
$0(0-8)$
\end{tabular} & $\begin{array}{l}1 \pm 2 ; \\
0(0-6)^{\mathrm{b}}\end{array}$ & 2 \\
\hline Puck & $3.9 \times 10^{1} \pm 8$ & $3.5 \times 10^{1} \pm 1.1 \times 10^{1}$ & 1 & \begin{tabular}{|l|}
$3 \pm 5$ \\
$0(0-8)$
\end{tabular} & 0.00 & 3 \\
\hline Gdynia & $2 \times 10^{1} \pm 1 \times 10^{1}$ & $1 \pm 1$ & 20 & 0.00 & 0.00 & - \\
\hline Sopot & $\begin{array}{l}3 \pm 2 \\
3(0-7)^{\mathrm{b}}\end{array}$ & $1 \pm 1$ & 3 & $\begin{array}{l}1 \pm 2 \\
0(0-6)\end{array}$ & 0.00 & 1 \\
\hline Gd.-Brzeźno ${ }^{a}$ & $\begin{array}{l}6.7 \times 10^{1} \pm 6.8 \times 10^{1} \\
5.5 \times 10^{1}\left(0-1.49 \times 10^{2}\right)^{b}\end{array}$ & $3 \pm 1$ & 22 & $\begin{array}{l}1.8 \times 10^{1} \pm 3.1 \times 10^{1} \\
7\left(0-9.5 \times 10^{1}\right)^{\mathrm{b}}\end{array}$ & 0.00 & 18 \\
\hline p-value ${ }^{c}$ & \multicolumn{2}{|l|}{0.025} & & \multicolumn{2}{|l|}{\begin{tabular}{|l|l|}
0.046 \\
\end{tabular}} & \\
\hline
\end{tabular}

Table 5. The mean and standard deviation of concentration of coliforms and E. coli $\left(\mathrm{CFU} / \mathrm{m}^{3}\right)$ in air over the Bay of Gdańsk in 2018 versus 2014-2017. a Gd.-Brzeźno-it is an abbreviation of the town name GdańskBrzeźno, bin case of a higher standard deviation than the mean, the median and range (min-max) was calculated, ${ }^{c}$ Friedman test, $\alpha-0.05$, ${ }^{\star}$ The results marked in grey colour have been published in preliminary study $^{36}$.

$\mathrm{p}=0.046$ ). The mean, median, and standard deviation values for the concentration of coliform bacteria and $E$. coli in SSA are presented in Table 5.

In 2018, in air samples collected in Hel, Sopot and Gdańsk-Brzeźno, a higher concentration of P. aeruginosa was detected, but not statistically significant $\left(\chi^{2}=1, \mathrm{df}=1, \mathrm{p}=0.317\right)$.

The concentration of $S$. aureus detected in the air in Sopot in 2018, was higher, but not statistically significant $\left(\chi^{2}=2, \mathrm{df}=1, \mathrm{p}=0.157\right)$, compared to 2014-2017 (Table 6).

The relationship between the concentration of bacteria detected in the air samples collected over the Bay of Gdańsk in the $\mathbf{5}$ coastal towns in 2018 compared to 2014-2017. The analysis, conducted using contingency tables, made it possible to assess the relationship between the concentration of bacteria detected in the air samples collected over the Bay of Gdańsk in Hel, Puck, Gdynia, Sopot and GdańskBrzeźno in 2018 compared to 2014-2017. Pearson chi-squared test of independence showed that in 2014-2017 in Gdynia, Sopot and Gdańsk-Brzeźno lower than expected concentrations of psychrophilic and mesophilic bacteria were observed, whereas in 2018 it was higher than expected. The result was statistically significant $\left(\chi^{2}=779.51, \mathrm{df}=4, \mathrm{p}=<2.22 \times 10^{-16}\right.$ vs $\left.\chi^{2}=681.25, \mathrm{df}=4, \mathrm{p}=<2.22 \times 10^{-16}\right)$ (Fig. $\left.2 \mathrm{~A}, \mathrm{~B}\right)$.

In 2014-2017, the mean concentration of coliforms in Hel was lower than expected, while in 2018 it was very close to the expected value according to the use of the independence test. In 2014-2017 and 2018, in Gdynia, Sopot and Gdańsk-Brzeźno, the concentration of coliforms was very close to the expected value. The result was statistically significant $\left(\chi^{2}=121.87, \mathrm{df}=4, \mathrm{p}=<2.22 \times 10^{-16}\right)$. In 2014-2017 and 2018 it was observed that in Hel, Puck, Gdynia, Sopot and Gdańsk-Brzeźno the mean concentration of $E$. coli was very close to the expected value. The result was not statistically significant $\left(\chi^{2}=5.63, \mathrm{df}=4, \mathrm{p}=0.2225\right)$ (Fig. $\left.2 \mathrm{C}, \mathrm{D}\right)$. 


\begin{tabular}{|c|c|c|c|c|c|c|}
\hline & $\begin{array}{l}\text { P. aeruginosa } \\
\left(\mathrm{CFU} / \mathrm{m}^{3}\right)\end{array}$ & $\begin{array}{l}\text { P. aeruginosa } \\
\left(\mathrm{CFU} / \mathrm{m}^{3}\right)\end{array}$ & Fold change & $\begin{array}{l}\text { S. aureus (CFU/ } \\
\left.\mathbf{m}^{3}\right)\end{array}$ & $\begin{array}{l}\text { S. aureus (CFU/ } \\
\text { m }^{3} \text { ) }\end{array}$ & Fold change \\
\hline Location & 2018 & 2014-2017 & $\begin{array}{l}\text { 2018 vs } \\
2014-2017\end{array}$ & 2018 & 2014-2017 & $\begin{array}{l}2018 \text { vs } \\
2014-2017\end{array}$ \\
\hline Hel & $\begin{array}{l}4 \times 10^{1} \pm 4.7 \times 10^{1} \\
3.2 \times 10^{1} \\
\left(0-9.5 \times 10^{1}\right)^{\mathrm{b}}\end{array}$ & $\begin{array}{l}1 \pm 2 ; \\
0(0-6)^{\mathrm{b}}\end{array}$ & 40 & $\begin{array}{l}6 \pm 8 \\
4\left(0-1.6 \times 10^{1}\right)^{b}\end{array}$ & $\begin{array}{l}2 \pm 6 \\
0\left(0-2 \times 10^{1}\right)^{b}\end{array}$ & 3 \\
\hline Puck & 0.00 & 0.00 & - & 0.00 & 0.00 & - \\
\hline Gdynia & 0.00 & $\begin{array}{l}5 \pm 1.0 \times 10^{1} \\
1\left(0-2.2 \times 10^{1}\right)^{b}\end{array}$ & - & 0.00 & 0.00 & - \\
\hline Sopot & $\begin{array}{l}2.9 \times 10^{1} \pm 6.1 \times 10^{1} \\
0\left(0-1.67 \times 10^{2}\right)^{\mathrm{b}}\end{array}$ & 0.00 & 29 & $\begin{array}{l}4 \pm 7 \\
0\left(0-1.9 \times 10^{1}\right)^{b}\end{array}$ & 0.00 & 4 \\
\hline Gd.-Brzeźno ${ }^{\mathrm{a}}$ & $\begin{array}{l}4.2 \times 10^{1} \pm 8.5 \times 10^{1} \\
0\left(0-2.36 \times 10^{2}\right)^{\mathrm{b}}\end{array}$ & 0.00 & 42 & 0.00 & 0.00 & - \\
\hline p-value ${ }^{c}$ & \multicolumn{2}{|l|}{0.317} & & \multicolumn{2}{|l|}{0.157} & \\
\hline
\end{tabular}

Table 6. The mean and standard deviation of concentration of $P$. aeruginosa and S. aureus $\left(\mathrm{CFU} / \mathrm{m}^{3}\right)$ in air over the Bay of Gdańsk in 2018 versus 2014-2017. ${ }^{a}$ Gd.-Brzeźno-it is an abbreviation of the town name Gdańsk-Brzeźno, bin case of a higher standard deviation than the mean, the median and range ( $\min -\max$ ) was calculated, ${ }^{\mathrm{c}}$ Friedman test, $\alpha-0.05$.

Also, in2014-2017 and 2018 in Hel, Sopot and Gdańsk-Brzeźno, the mean concentration of the P. aeruginosa in the air was close to the expected concentration. The result was statistically significant $\left(\chi^{2}=87.02, \mathrm{df}=4\right.$, $\left.\mathrm{p}=<2.22 \times 10^{-16}\right)$. In 2014-2017 and 2018 in Hel and Sopot, the concentration of S. aureus was very close to the expected concentration according to the use of the independence test. However, the result was not statistically significant $\left(\chi^{2}=1.25, \mathrm{df}=4, \mathrm{p}=0.878\right)$ (Fig. $\left.2 \mathrm{E}, \mathrm{F}\right)$.

The effect of meteorological parameters on the concentration of bacteria in the air in 5 coastal towns located on the Bay of Gdańsk. The impact of meteorological parameters (relative humidity, air temperature, wind speed and direction) on the concentration of psychrophilic and mesophilic bacteria, coliforms, E. coli, P. aeruginosa and S. aureus in the air over the Bay Gdańsk in 2018 and 2014-2017 was examined. With the use of Spearman's correlation a statistically significant positive relationship between the relative humidity of the air over the Bay of Gdańsk and the concentration of psychrophilic bacteria $(R s=0.368, p=0.0002)$ and mesophilic bacteria ( $\mathrm{Rs}=0.323, \mathrm{p}=0.001$ ) was observed. The results of Spearman's correlation analysis showed a statistically significant positive relationship between the temperature of air in the Bay of Gdańsk and the concentration of psychrophilic bacteria $(R s=0.235, p=0.02)$, mesophilic bacteria $(R s=0.198, p=0.05)$, coliforms $(\mathrm{Rs}=0.489, \mathrm{p}=0.0001)$, E. coli $(\mathrm{Rs}=0.289, \mathrm{p}=0.005)$ and $S$. aureus $(\mathrm{Rs}=0.305, \mathrm{p}=0.002)$. Using Spearman's correlation, a statistically significant positive relationship was observed between the wind speed measured in 5 coastal towns, and the concentration of psychrophilic bacteria (Rs $=0.301, \mathrm{p}=0.003)$ and mesophilic bacteria $(\mathrm{Rs}=0.3, \mathrm{p}=0.003)$. The concentration of bacteria in the air over the Bay of Gdańsk in Hel, Puck, Gdynia, Sopot and Gdańsk-Brzeźno was also correlated with the wind direction. The results of the Kruskal-Wallis test showed a statistically positive correlation between the wind direction and the concentration of psychrophilic bacteria $\left(\chi^{2}=53.992, \mathrm{df}=16, \mathrm{p}=5.201 \times 10^{-6}\right)$ and mesophilic bacteria $\left(\chi^{2}=50.706, \mathrm{df}=16, \mathrm{p}=1.768 \times 10^{-5}\right)$. Moreover, a statistically significant positive relationship was observed between the wind direction and the concentration of coliforms $\left(\chi^{2}=39.697, \mathrm{df}=16, \mathrm{p}=0.0008\right)$, P. aeruginosa $\left(\chi^{2}=25.275, \mathrm{df}=16, \mathrm{p}=0.065\right)$ and $S$. aureus $\left(\chi^{2}=39.697, \mathrm{df}=16, \mathrm{p}=0.0008\right)$.

Bacterial emission from the sea-surface microlayer to atmospheric air in 5 coastal towns on the Bay of Gdańsk. We assessed whether SML emissions led to bacterial enrichment of the air in the coastal towns of Hel, Puck Gdynia, Sopot and Gdańsk-Brzeźno. Based on the two-sample.

t-test, in 2018 higher enrichment values were found with respect to psychrophilic bacteria in Sopot and Gdańsk-Brzeźno compared to 2014-2017. The results were positively correlated but were not, statistically significant $(\mathrm{p}=0.573)$. The maximum enrichment factor for aerosolized psychrophilic bacteria in Sopot was 9 in 2018, compared to 0 in 2014-2017. The maximum enrichment factor for psychrophilic bacteria in Gdańsk-Brzeźno was 4 in 2018 compared to 2 in 2014-2017. A greater enrichment factor of mesophilic bacteria was also observed in the air in the above-mentioned cities; however, this was not statistically significant $(\mathrm{p}=0.623)$. The maximum enrichment factor for mesophilic bacteria was found in 2018 compared to 2014-2017, respectively, in Sopot (18) vs (1) and Gdańsk-Brzeźno (3) vs (2). Higher, but not statistically significant $(\mathrm{p}=0.419)$ enrichment factors in coliform bacteria were found in 2018 compared to the analysis carried out in 2014-2017, respectively, in Hel (768) vs (4), Gdynia (11) vs (1), Sopot (24) vs (2) and Gdańsk-Brzeźno (80) vs (15). The maximum enrichment factor for E. coli in Hel was 102 in 2018, compared to 33 in 2014-2017 and in Gdańsk-Brzeźno was 73 in 2018, compared to 0 in 2014-2017 but not statistically significant $(\mathrm{p}=0.1)$. The maximum enrichment factor for $P$. aeruginosa in Sopot was 61 in 2018, without being statistically significant on the Wilcoxon rank sum test with continuity correction $(\mathrm{p}=1)$. The maximum air enrichment factor for S. aureus in Gdańsk-Brzeźno was 8 in 2018 , compared to 3 in 2014-2017. The result was positively correlated $(p=0.033)$. 

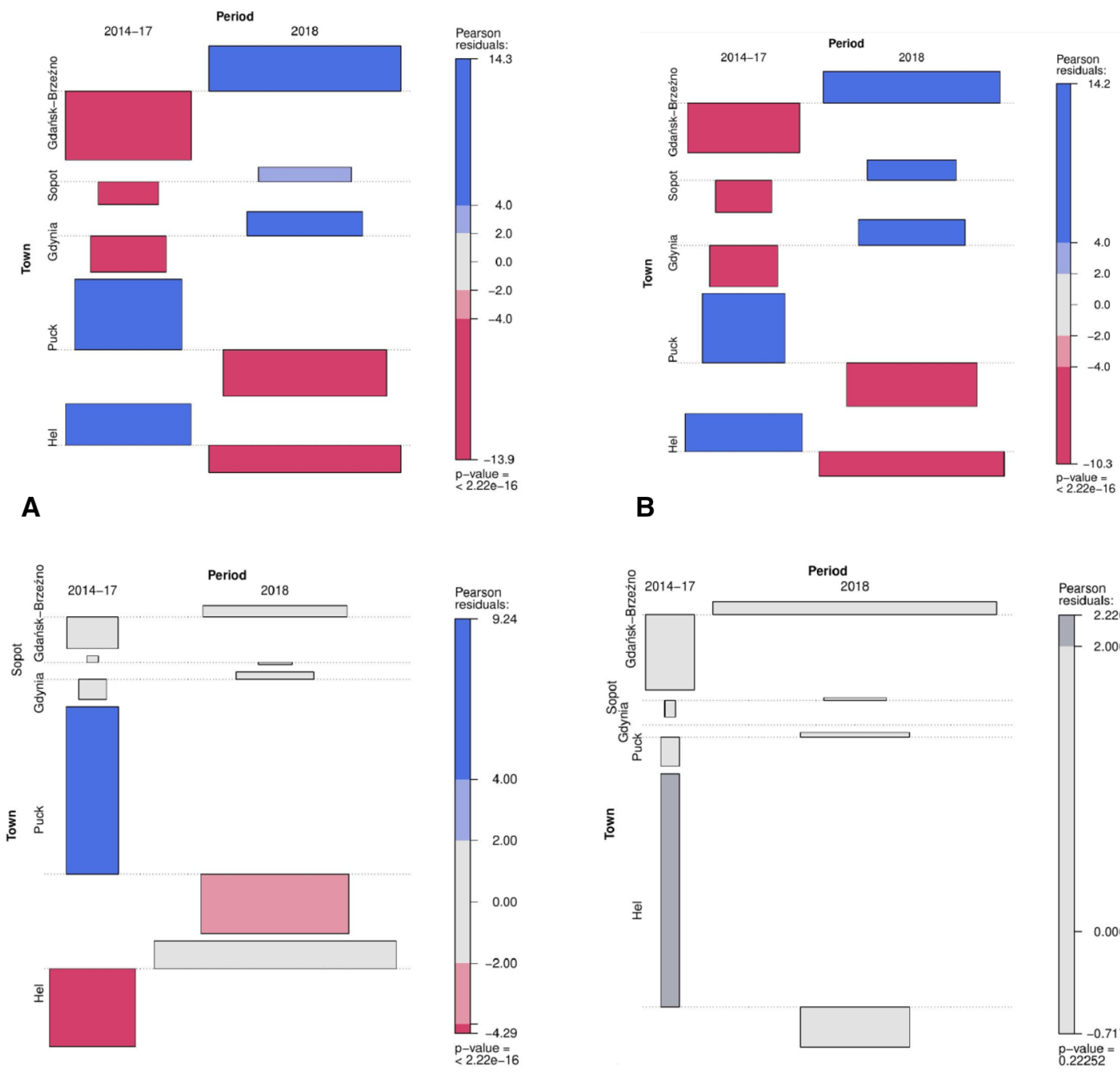

\section{$\mathbf{B}$}
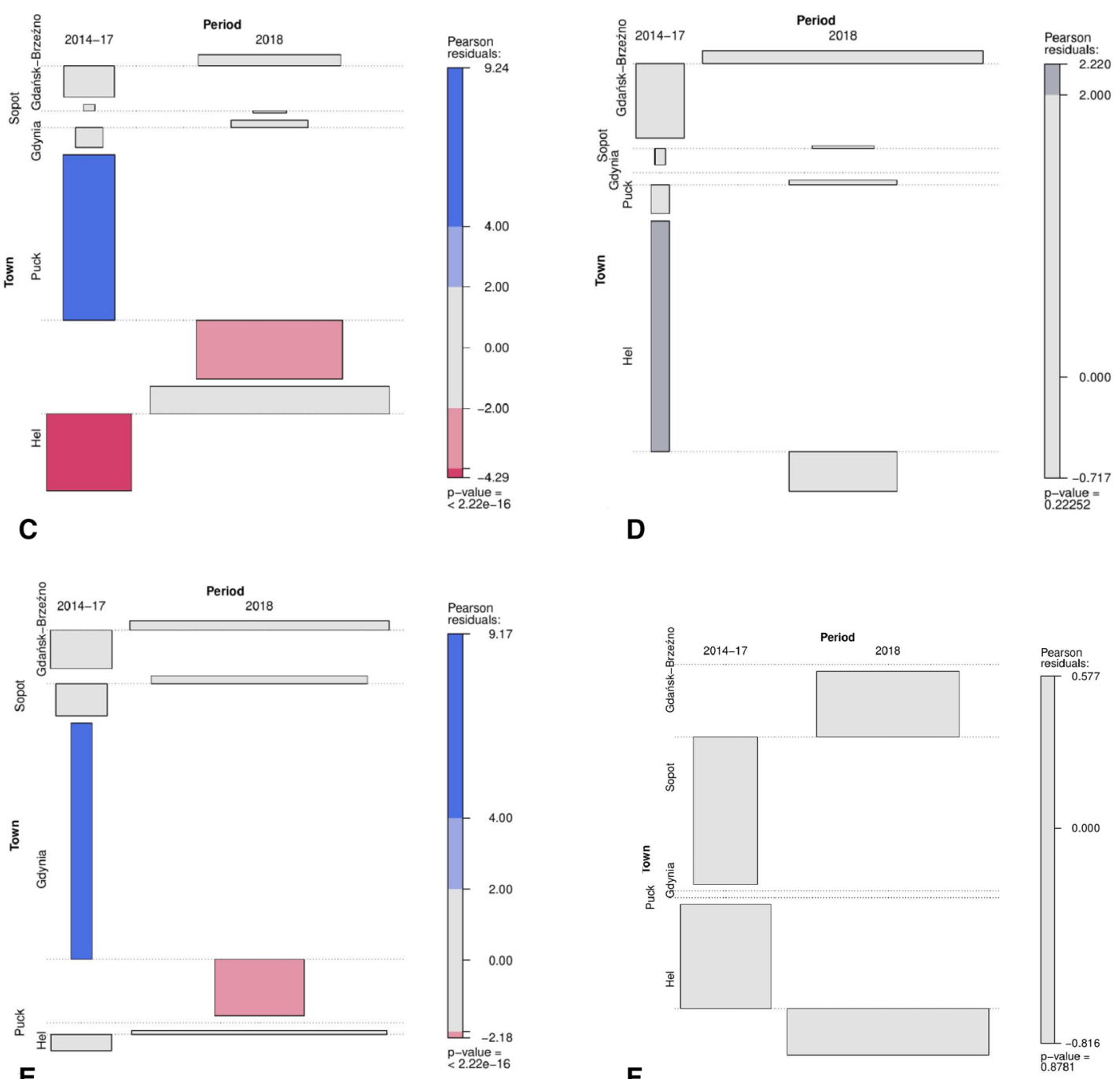

D

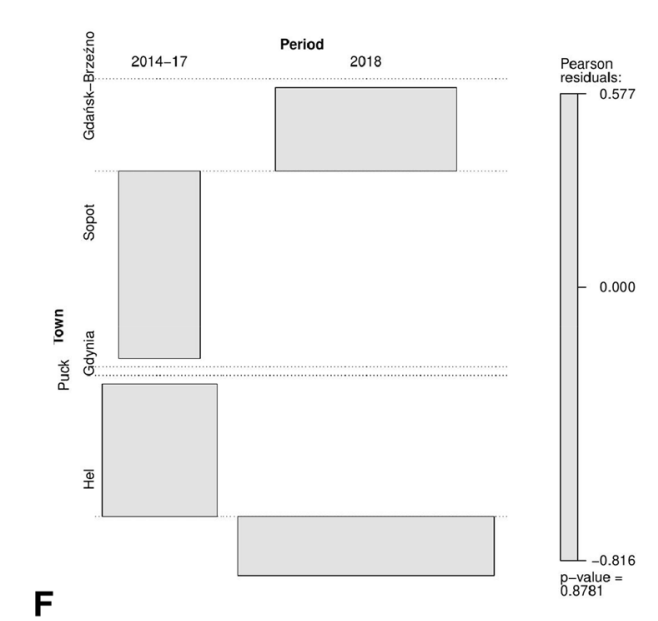

Figure 2. The association of the contingency table with the mean quantity of psychrophilic (A) and mesophilic bacteria (B), coliform (C) and E. coli (D) bacteria, P. aeruginosa $(\mathbf{E})$ and S. aureus $(\mathbf{F})$ bacteria detected in the air samples collected from the Bayof Gdańsk in Hel, Puck, Gdynia, Sopot and Gdańsk-Brzeźno and the time period for the sample collection (2014-2017 and 2018). The blue colour indicates that the observed value is higher than the expected value if the data was random. The red colour specifies that the observed value is lower than expected and the grey colour indicates that the observed value is close to the expected. 


\section{Discussion}

Samples collected in 2018 after an emergency discharge of sewage to the Bay of Gdańsk showed a statistically significant, higher concentration of psychrophilic and mesophilic bacteria in the sea-surface microlayer and air over the Bay of Gdańsk (Hel, Sopot, Gdańsk-Brzeźno) compared to 2014-2017. In 2018, a greater concentration of coliforms wasdetected in water samples collected from the Bay of Gdańsk in Puck, Sopot and Gdańsk-Brzeźno. In addition, a higher concentration of E. coli was found in water samples collected in Puck and Gdańsk-Brzeźno. In 2018, a significantly greater concentration of coliforms was detected in the air in Hel, Puck, Gdynia, Sopot and Gdańsk-Brzeźno compared to 2014-2017. Moreover in 2018, in Hel, Puck, Sopot and Gdańsk-Brzeźno, a statistically significant, higher concentration of E. coli was detected in the air. Pearson's chi-squared test and the multidimensional data analysis, conducted using contingency tables, showed a statistically significant positive correlation between the concentration of psychrophilic, mesophilic and coliform bacteria in the water and air in 2018 compared to 2014-2017. These results suggest that the increased concentration of mesophilic bacteria, coliforms and $E$. coli in the seawater of the Bay of Gdańsk and in the coastal air could have been the result of an emergency discharge of raw sewage in 2018. For example, in Kuwait, after a failure at the Mishref sewage pumping station, a greater concentration of coliforms, E. coli and faecal streptococci was detected in the waters of Kuwait Bay ${ }^{29}$. The authors showed that the raw sewage discharged for 3 years (2009-2012), directly into the bay, bacteriologically contaminated approximately $20 \mathrm{~km}$ of the coast ${ }^{29}$. In another study, Poté et al. (2009) have found that rainwater and sewage flowing out of an underwater collector at a depth of $30 \mathrm{~m}$ had the greatest impact on the pollution of the waters of the Bay of Vidy, Lake Geneva, Switzerland ${ }^{28}$.

An attempt was made at the next stage of our research to assess the impact of temperature, humidity, wind speed and wind direction on the presence of bacteria in the air of the coastal towns of Hel, Puck, Gdynia, Sopot and Gdańsk-Brzeźno, after an emergency discharge of sewage into the Bay of Gdańsk. There was a positive relationship between airborne bacteria (psychrophilic andmesophilic bacteria, coliforms, E. coli, S. aureus) and the air temperature. It is possible that UV radiation can quickly destroy airborne bacteria. However, the outdoor atmospheric bacteria can tolerate extreme sunlight and moderately high temperatures due to their spore form and pigments ${ }^{40-42}$. According to Aller et al. (2005) some bacteria and viruses are likely embedded in transparent gel-like organic particles that can provide some degree of physical protection against UV radiation and drying ${ }^{43}$.

Moreover, there wasa statistically significant relationship between relative humidity and the concentration of psychrophilic and mesophilic bacteria in coastal towns. Recent studies of bioaerosols by other authors have also shown that the relative humidity of the air can affect the species composition of microorganisms and their survival in the air ${ }^{44,45}$. Brągoszewska and Pastuszka showed thathigh relative humidity may result in cell clumping, which possibly increases the odds of microorganism survival ${ }^{45}$. Our study showed a statistically significant, positive relation between a higher concentration of psychrophilic and mesophilic bacteria, coliforms and $S$. aureus and the wind blowing from the north and north-east (i.e. from the sea towards the land). In microbiological air tests conducted by Montero et al. (2016) along the quay in Flushing Bay, Queens, New York (USA), correlations were found between the concentration of microorganisms in the coastal air and the wind direction. The total concentration of bacteria detected in air samples taken along the coast was higher when the wind was blowing from the sea. When the wind was blowing from the land, a higher concentration of fungal mould spores was detected ${ }^{46,47}$. Our study indicates a statistically significant relationship between the wind speed and the concentration of psychrophilic and mesophilic bacteria after an emergency discharge of sewage into the Bay of Gdańsk. The results of our team's research have shown for the first time ever that air velocity plays a key role in bacterial emissions from marine coastal water of the Bay of Gdańsk to coastal air ${ }^{48-50}$. What's more, it has also been shown that the process of breaking wind waves is also influenced by wind speed, which causes the formation of bubbles in seawater ${ }^{48,51}$. The bubbles selectively accumulate hydrophobic matter and microorganisms, which are transported towards the water surface and are partially emitted into the air $\left[{ }^{51-55}\right]$. For example Uetake et al. showed that the wind speed was positively correlated with wave height in Tokyo Bay. High wind speeds above the bay's surface correlated with greater aerosol production by the bubble bursting process during breaking waves, especially on the shore ${ }^{55}$. Other researchers found thatthe viable and total bacterial concentrations was significantly higher when the wind speed was greater than $5.4 \mathrm{~m} \mathrm{~s}^{-1}$ (exceeding a Beaufort force of 3 , at which wave breaking can occur) ${ }^{53}$. Dukier et al. also showed a positive correlation between wind speed and the amount of bacteria and viruses in the coastal air along the urban wharf at Louis Valentino Pier in the harbour of Brooklyn and Flushing Bay (FB), Queens, New York, (USA) ${ }^{5}$. Interesting observations were also presented byRahlff et al., they showed that enrichment of bacteria in the SML occurred solely at a $U_{10}$ wind speed of $\leq 5.6 \mathrm{~m} \mathrm{~s}^{-1}$ in the tunnel and $\leq 4.1 \mathrm{~m} \mathrm{~s}^{-1}$ in the Baltic Sea ${ }^{56}$.

And finally, our study showed a clear tendency of SSAenrichment with psychrophilic, mesophilic bacteria, and E. coli and P. aeruginosa in Sopot and Gdańsk-Brzeźno. The high, although not statistically significant, factor of air enrichment with coliforms was detected in 2018 in Hel, Gdynia, Gdańsk-Brzeźno and Sopot. The high factor of air enrichment with mesophilic bacteria, coliforms, E. coli, P. aeruginosa or S. aureus may be associated with the emergency discharge of wastewater into the Motława River flowing into the Bay of Gdańsk. Therefore, it is suggested that in the event of a malfunction of a sewage treatment plant, as well as after floods or sudden rainfall, the public should be informed about the sanitary and epidemiological status of the coastal waters and be recommended to limit their use of coastal leisure areas.

In our previous studies, at the mouth of the Vistula River, we showed a 12-fold greater enrichment rate in SSA for mesophilic, potentially pathogenic bacteria compared to psychrophilic bacteria ${ }^{48}$. We also provided evidence that oxygen supersaturation in the surface water may contribute to enhanced bubble-mediated seato-air bacteria transport, in particular during the presence of a summer phytoplankton bloom in the Gulf of Gdańsk ${ }^{48}$. Blanchard and Syzdek (1970) were the first to study the phenomenon of enrichment of marine aerosols drops with bacteria. The authors demonstrated that air bubbles breaking at the air-water interface can remove 
bacteria that concentrate in the surface microlayer and eject them into the atmosphere. The bacterial concentrations in the drops ejected from the bubbles may, depending on the drop size, be from 10 to 1000 times that of the water in which the bubbles burst ${ }^{54}$. In turn, other researchers showed 15-25 fold enrichment in bacteria and viruses during transport from SML into the atmosphere. The data support the idea that the SML is a major source of microorganisms entering the atmosphere from water bodies ${ }^{43}$. It should be kept in mind that studying aerosols in nature is extremely difficult as, confounding factors such as ocean and atmospheric circulation patterns prevent convolution of terrestrial and marine sources of airborne microbes ${ }^{38,56,57}$. The mechanism is based on the mutual attraction of negatively charged bacterial cells by cationic vortexes formed below the bubbles. The scavenging of microorganisms in seawater depends on the bubble' size, the value of the negative charge of anions accumulated on the outer membranes and the charge of the cations accumulated in the vortex under the bubble ${ }^{52,58}$. Further research is needed, both in the laboratory and marine waters, to understand the "transport" of microorganisms in detail.

Study limitations. The present study has some limitations that we would like to address. First, the studies presented were based on the assessment of the concentration of bacteria grown on microbiological media (described in the Materials and methods section). Not all live bacteria may grow on the microbiological plates, so the concentration of live bacteria in the surface microlayer and sea spray may have been greatly underestimated. Second, most studies on the microorganisms in the sea-surface microlayer have been conducted in the open ocean and coastal water, but studies from the Bay of Gdańsk after an emergency discharge of raw sewage are not available.

\section{Materials and methods}

Collection of aerosol and seawater samples. In the years 2014-2018, a total of 408 air samples and 186 sea-surface microlayersamples were collected in 5 coastal towns (Hel, Puck, Gdynia, Sopot and Gdańsk-Brzeźno) in the Bay of Gdansk. In the years 2014-2017, the air samples were collected between the 22nd of May and 22nd of July, every 20 days between 9:00 a.m. and 2:00 p.m. In 2018, after an emergency disposal of raw sewage, the air samples were collected between the 22nd of May and 22nd of July, every 11 days between 9:00 a.m. and 2:00 p.m. Air and water samples were not collected under rainy conditions. The air samples were collected for 10 min by impaction with a SAS Super ISO 100 (Milan, Italy) sampler. The nozzle of the sampler was positioned perpendicularly to the wind direction. The sampler automatically collected 100-L samples of air. The microorganisms passed through small holes in the sampler, directly on to Petri dishes containing an agar medium appropriate for each type of organism. The maximum efficiency of collection is for particulate matter with a d50 $=2-4 \mu \mathrm{m}$. The flow rate is $90 \mathrm{lpm}$. All removable parts of the air sampler were sterilized by autoclaving before sampling and the sterilized sampler head was cleaned between samples with a $70 \%$ ethanol solution ${ }^{17}$. The samples of seawater were collected from the microlayer $(\mathrm{SML}) \leq 100 \mu \mathrm{m}$ with a sterile $3 \mathrm{~mm}$ thick glass plate sized $50 \mathrm{~cm} \times 50 \mathrm{~cm}$. The plate was immersed in the seawater at an angle of 45 degrees and once the surface of the water was stable the plate was pulled out with a vigorous movement. Water from both sides of the plate was removed with a rubber wiper into sterile glass bottles ${ }^{59,60}$. The samples of water from the sea microlayer were stored in a cooling container at $4{ }^{\circ} \mathrm{C}$ and delivered to the laboratory within $4 \mathrm{~h}$ from collection for further analysis ${ }^{36}$.

Microbiological analysis of bioaerosols. The concentration of mesophilic bacteria in the air samples was determined on trypticase soy agar (TSA) by Merck/Germany, after a $24-48$-h incubation period at $37^{\circ} \mathrm{C}$. For psychrophilic bacteria culture TSA agar was used. The incubation was carried out at $22^{\circ} \mathrm{C}$ for $72 \mathrm{~h}$. The concentration of coliforms and Escherichia coli was determined on Chromocult ${ }^{\circledR}$ Coliform Agar by Merck/Germany, after a 24 -h incubation period at $37^{\circ} \mathrm{C}$. The concentration of Pseudomonas aeruginosa bacteria was determined on Cetrymide agar by Merck/Germany after a 24 -h incubation period at $37^{\circ} \mathrm{C}$. The concentration of Staphylococcus sp. was determined on Mannitol Salt Agar (MSA) by Merck/Germany. Confirmatory tests involved making Gram stained preparations, performing tests for the presence of aminopeptidase and catalase enzymes, and confirming the ability of the studied bacteria to ferment glucose in anaerobic conditions. Staphylococcus aureus was also differentiated from Staphylococcus epidermis saprophytic strains with the rabbit plasma test. The concentration of bacteria was expressed as a colony-forming unit (CFU) per $1 \mathrm{~m}^{3}$ of air $\left(\mathrm{CFU} / \mathrm{m}^{3}\right)$. To calculate the number of microorganisms in the air samples, the Feller measuring table attached to the air sampler manual was used ${ }^{61}$. The concentration of bacterial colonies $\left(\mathrm{CFU} / \mathrm{m}^{3}\right)$ was calculated using the equation contained in the publication ${ }^{17}$.

The colonies collected should be revised by the Eq. (1)

$$
\operatorname{Pr}=\mathrm{N}(1 / \mathrm{N}+1 / \mathrm{N}-1+1 / \mathrm{N}-2+1 / \mathrm{N}-\mathrm{r}+1)
$$

where $\mathrm{Pr}$ is the revised colony in stage, $\mathrm{N}$ is the concentration of sieve pores, and $\mathrm{r}$ is the concentration of viable particles counted on the agar plate.

The concentration of bacterial colonies $\left(\mathrm{CFU} / \mathrm{m}^{3}\right)$ was calculated using the following Eq. (2)

$$
\mathrm{C}(\mathrm{CFU} / \mathrm{m} 3)=\mathrm{T} \times 1000 \mathrm{t}(\mathrm{min}) \times \mathrm{F}(\mathrm{L} / \mathrm{min})
$$

where C - airborne bacteria concentration; CFU - colony-forming unit; $\mathrm{T}$ - total colonies after application of the Pr statistical correction; $\mathrm{t}$ - sampling time and $\mathrm{F}$ - airflow rate.

Enumeration of bacteria in the air was conducted according to the Polish Standard (PN-89 Z-04111/02Air purity protection, Microbiological testing, Determination concentration of bacteria in the atmospheric air (emission) with sampling by aspiration and sedimentation method 1989) ${ }^{62}$. We also used theNIOSH Manual 
of Analytical Methods (2003-154) - Method Number 0-2000 and the general provisions for EPA-Sampling, Laboratory, and Data Considerations for Microbial Data Collected in the Field ${ }^{63}$.

Microbiological analysis of sea-surface microlayer. The overall concentration of psychrophilic and mesophilic bacteria was determined with the pour plate method after incubation of $1 \mathrm{ml}$ of seawater on tryptic soy agar from Merck (Germany). The results were read after $72 \mathrm{~h}$ and $48 \mathrm{~h}$ of incubation at $22^{\circ} \mathrm{C}$ and $37^{\circ} \mathrm{C}$. The colony-forming unit count was used to determine the concentration of bacteria in $1 \mathrm{ml}$ seawater samples (CFU/ $\mathrm{ml}$ ). The determined pour plate method and membrane filtration method were used to study the water samples, according to the Polish Standard PN-ISO $6222^{64}$ and to the American Public Health Association standard ${ }^{65}$. Water samples (SML) of $100 \mathrm{ml}$ each were filtrated through sterile filters (pore size $0.45 \mu \mathrm{m}$ ) and then placed on selective agar mediums. The concentration of coliform bacteria was estimated on Chromocult ${ }^{\star}$ Coliform Agar by Merck/Germany after 24-h of incubation at $37^{\circ} \mathrm{C}$, according to the Polish Standard PN-EN ISO 93081:2014-12 $2^{66}$. The P. aeruginosa bacteria concentration was determined on Cetrymide Agar by Merck/Germany after 24-h of incubation at $37^{\circ} \mathrm{C}$, according to the Polish Standard PN-EN ISO 16266:200967. The concentration of Staphylococcus sp. was determined on MSA by Merck (Germany) according to the standard developed by the Polish Hygiene Institute PB-01-PM-NIZP-PZH ZHK:2007 ${ }^{68}$. The colony-forming unit (CFU/ml) was used to determine the concentration of bacteria in $100 \mathrm{ml}$ of SML. Gram-stained preparations were made. Tests for the presence of aminopeptidase and catalase enzymes and confirmation of the ability of the studied bacteria to ferment glucose under anaerobic conditions were performed. S. aureus was differentiated from S. epidermis by a tube coagulase test ${ }^{36}$. Microbiological research of seawater in coastal bathing areas was carried out in accordance with the Regulation of the Minister of Health of January 17, 2019 on the supervision of the quality of water in bathing areas and occasional recreational places (Dz. U. z 2019, poz. 255), the Bathing Water Directive (Directive 76/160/EEC 2006) and Water Law (Journal of Laws of 2018, item 2268, as amended) ${ }^{69-71}$.

Characterization of meteorological conditions. During the collection of samples between spring and summer during 2014-2017 and in 2018, air temperature, humidity, wind speed and wind direction were recorded using a GMH 3330 thermo-hygrometer by Greisinger (Germany). The air temperature during 20142017 ranged from $3{ }^{\circ} \mathrm{C}$ to $26^{\circ} \mathrm{C}$ (spring season), and from 16 to $20^{\circ} \mathrm{C}$ (summer season). Relative humidity during spring was between 30 and $88 \%$, and from 59 to $82 \%$ during summer. Wind speed during spring varied between 0 and $31 \mathrm{~km} \mathrm{~h}^{-1}$, and between 7 and $25 \mathrm{~km} \mathrm{~h}^{-1}$ in the summer. The air temperature in 2018 fluctuated between 1 and $27^{\circ} \mathrm{C}$ in the spring, and between 15 and $27^{\circ} \mathrm{C}$ during summer. Relative humidity in the spring season ranged between 39 and $93 \%$, and from 44 to $70 \%$ in the summer season. Wind speed during spring varied between 0 and $15 \mathrm{~km} \mathrm{~h}^{-1}$, and between 2.6 and $32 \mathrm{~km} \mathrm{~h}^{-1}$ in the summer ${ }^{36}$.

Model evaluation of bacterial emission from SML to atmospheric air. In order to assess bacterial emission from seawater to atmospheric air we calculated the enrichment factor (EF) according to the following formula ${ }^{72,73}$ :

$$
\mathrm{EF}=\mathrm{L}_{\mathrm{A}} / \mathrm{L}_{\mathrm{W}}
$$

where $\mathrm{L}_{\mathrm{A}}$-oncentration of bacteria in sea aerosols (CFU/1 ml), $\mathrm{L}_{\mathrm{W}}$-concentration of bacteria in the sea surface microlayer in the Bay of Gdańsk (CFU/1 ml).

The concentration of bacteria in marine aerosol $\left(\mathrm{L}_{\mathrm{A}}\right)$ was calculated from the formula:

$$
\mathrm{L}_{\mathrm{A}}=\mathrm{L} / \mathrm{A}(\mathrm{ml})
$$

where $\mathrm{L}-$ concentration of bacteria in the air $\left(\mathrm{CFU} / \mathrm{m}^{3}\right), \mathrm{A}-$ volume of sea derived droplets in air for a given wind speed $\mathrm{u}(10), \mathrm{A}=\exp \left((-2.62+0.59 \mathrm{u}(10)) 0.142857\left(\mathrm{ml} / \mathrm{m}^{3}\right)\right.$.

Where: $0.142857=(1000 / 7) 10-3,7 \%$ is the mean salinity of the Baltic Sea within $(7-8 \%$ ), the value of $7 \%$ salinity fits to the range of calculations considered in our model, while 10-3 results from the conversion of $\mu \mathrm{g} /$ $\mathrm{ml}$, assuming the density of water at $1 \mathrm{~g} / \mathrm{ml}$.

$\mathrm{u}(10)$ is the wind speed in $\mathrm{m} / \mathrm{s}$ measured $10 \mathrm{~m}$ above the surface of water, under the conditions of a wind fetch over the sea of at least $5-10 \mathrm{~km}$.

Statistical analysis. A Pearson's chi-squared test for independence was performed to assess significant differences between the categorical variable: for one "sample collection years" (two subgroups; 2014-2017 and 2018), and for the second categorical variable:"place" (five subgroups: Hel, Puck, Gdynia, Sopot and GdańskBrzeźno). The contingency tables obtained this way are presented in the form of association figures with the values of Pearson's residuals and the $\mathrm{p}$ value of the independence test ${ }^{74}$. Association plots visualize the table of Pearson residuals: each cell is represented by a rectangle that has a height proportional to the corresponding Pearson residual and width proportional to the square root of the expected value. Thus, the area is proportional to the raw residuals. The rectangles representing each cell in the table are positioned relative to a line representing independence. Cells with an observed frequency greater than expected are shown above the line and cells with an observed frequency lower than expected are shown below the line $\mathrm{e}^{75}$.

In each of the association figures, the blue colour means that there are more observations than would be expected if the data was random. Negative Pearson residuals (the red colour) means that the cell values were smaller than expected. The grey colour represents the data where the concentrations are close to the expected, i.e., the null hypothesis of the independence test is true. To assess the differences between the mean concentration of bacteria detected in seawater and air in the two time periods, 2014-2017 and in 2018, the non-parametric 
Friedman rank sum test was used. To assess the differences between bacterial aerosol concentrations and meteorological parameters, the Kruskal-Wallis ANOVA non-parametric test was used, and the Spearman correlation was determined. In order to compare the bacterial enrichment of the seawater to air between 2014-2017 and 2018, we used the following tests: a two-sample t-test (where the Shapiro-Wilk test showed that the compared groups are from a normal distribution population) and the Wilcoxon rank sum test with continuity correction (for all other cases). The statistical significance of the differences between the groups was set at $\mathrm{p}<0.05$. Statistical analysis of the results was carried out using software $\mathrm{R}(2018)^{76}$.

Received: 13 May 2021; Accepted: 7 October 2021

Published online: 25 October 2021

\section{References}

1. Gulia, S. et al. Ambient air pollutant monitoring and analysis protocol for low and middle income countries: An element of comprehensive urban air quality management framework. Atmos. Environ. 222, 17120 (2020).

2. Palladino, G. et al. Particulate matter emission sources and meteorological parameters combine to shape the airborne bacteria communities in the Ligurian coast, Italy. Sci. Rep. 11, 175 (2021).

3. Fewtrell, L. \& Kay, D. Recreational water and infection: A review of recent findings. Curr. Environ. Health Rep. 2(1), 85-94 (2015).

4. Walser, S. M. et al. Evaluation of exposure-response relationships for health effects of microbial bioaerosols-A systematic review. Int. J. Hyg. Environ. Health 218(7), 577-589 (2015).

5. Dueker, M. et al. Comparison of bacterial diversity in air and water of a major urban center. Front. Microbiol. 9, 2868 (2018).

6. O’Mullan, G. D., Dueker, E. M. \& Juhl, A. R. Challenges to managing microbial fecal pollution in coastal environments: Extraenteric ecology and microbial exchange among water, sediment, and Air. Curr. Pollut. Rep. 3, 1 (2017).

7. Rodrigues, C. \& Cunha, M. Â. Assessment of the microbiological quality of recreational waters: Indicators and methods, EuroMediterr. J. Environ. Integr. 2(1), 25 (2017).

8. Cabral, J. P. Water microbiology. Bacterial pathogens and water. Int. J. Environ. Res. Public Health 7(10), 3657-3703 (2010).

9. Arnold, B. F. et al. Acute gastroenteritis and recreational water: Highest burden among young US children. Am. J. Public Health 106(9), 1690-1697 (2016).

10. Jang, J. et al. Environmental Escherichia coli: Ecology and public health implications-A review. J. Appl. Microbiol. 123, 570-581 (2017).

11. Adeniji, O. O., Sibanda, T. \& Okoh, A. I. Recreational water quality status of the Kidd's Beach as determined by its physicochemical and bacteriological quality parameters. Heliyon 5(6), e01893. https://doi.org/10.1016/j.heliyon.2019.e01893 (2019).

12. Wade, T. J., Pai, N., Eisenberg, J. N., Colford, J. M. Jr. \& Do, U. S. Environmental Protection Agency water quality guidelines for recreational waters prevent gastrointestinal illness? A systematic review and meta-analysis. Environ. Health Perspect. 111(8), $1102-1109$ (2003).

13. DeFlorio-Barker, S. et al. Estimate of incidence and cost of recreational waterborne illness on United States surface waters. Environ. Health https://doi.org/10.1186/s12940-017-0347-9 (2018).

14. Li, J. \& Zhang, X. Beach pollution effects on health and productivity in California. Int. J. Environ. Res. Public Health 16(11), 1987 (2019).

15. Barreras, H. Jr., Kelly, E. A., Kumar, N. \& Solo-Gabriele, H. M. Assessment of local and regional strategies to control bacteria levels at beaches with consideration of impacts from climate change. Mar. Pollut. Bull. 138, 249-259 (2019).

16. Michalska, M. et al. PM10 concentration and microbiological assessment of air in relation to the concentration of acute cases of type 1 diabetes mellitus in the Lubelskie Voivodeship. Preliminary report. Pediatr Endocrinol Diabetes Metab. 23(2), 70-76 (2017).

17. Michalska, M. et al. Potential effects of microbial air quality on the concentration of new cases of diabetes type 1 in children in two regions of Poland: A pilot study. Infect. Drug Resist. 12, 2323-2334 (2019).

18. Quant, B. et al. Studies on disinfection of treated sewage discharged to surface water. Monografie Komitetu Inżynierii Środowiska PAN. 61(4), 19-29 (2009) (in Polish).

19. Hachich, E. M. et al. Comparison of thermotolerant coliforms and Escherichia coli densities in freshwater bodies. Braz. J. Microbiol. 43(2), 675-681 (2012).

20. Bumadian, M. M., Bozakouk, I. H., Lawgali, Y. F. \& Bleiblo, F. Detection and enumeration of coliform bacteria in drinking water at hospital of Benghazi/Libya. J. Exp. Biol. Agric. Sci. 1(6), 436-440 (2013).

21. Caruso, G. \& Caruso, R. Escherichia coli viability in coastal marine environments: A case study. J. Clin. Microbiol. Biochem. Technol. 1(1), 020-027 (2015).

22. Karbasdehi, V. N. et al. Indicator bacteria community in seawater and coastal sediment: The Persian Gulf as a case. J. Environ. Health Sci. Eng. 15, 6 (2017).

23. Newton, R. J. \& McClary, J. S. The flux and impact of wastewater infrastructure microorganisms on human and ecosystem health. Curr. Opin. Biotechnol. 57, 145-150 (2019).

24. Szumilas, T., Michalska, M. \& Bartoszewicz, M. Characteristics of bacterial contamination of municipal wastewater from a large urban agglomeration and evaluation of the reduction of pollution in wastewater treatment. Roczn. PZH. 52(2), 155-165 (2001) (in Polish).

25. Łuczkiewicz, A., Jankowska, K., Fudala-Książek, S. \& Olanczuk-Neyman, K. Antimicrobial resistance of faecal indicators in municipal wastewater treatment plant. Water Res. 44(17), 5089-5097 (2010).

26. Al-Gheethi, A. A. et al. Removal of pathogenic bacteria from sewage-treated effluent and biosolids for agricultural purposes. Appl. Water Sci. 8, 74 (2018).

27. Michalska, M. \& Bartoszewicz, M. The sanitary state of Pomeranian Bay and Gulf of Gdańsk waters during the flood of 1997. Dtsch. Hydrogr. Zeitschrift 50, 265-272 (1998).

28. Poté, J. et al. Origin and spatial-temporal distribution of faecal bacteria in a bay of Lake Geneva, Switzerland. Environ. Monit. Assess. 154(1-4), 337-348 (2009).

29. Lyons, B. P. et al. Microbial water quality and sedimentary faecal sterols as markers of sewage contamination in Kuwait. Mar. Pollut. Bull. 100(2), 689-698 (2015).

30. Margesin, R. \& Miteva, V. Diversity and ecology of psychrophilic microorganisms. Res. Microbiol. 162(3), 346-361 (2011).

31. Papciak, D. et al. The impact of the quality of tap water and the properties of installation materials on the formation of biofilms. Water 11, 1903 (2019).

32. Mena, K. D. \& Gerba, C. P. Risk assessment of Pseudomonas aeruginosa in water. Rev. Environ. Contam. Toxicol. 201, 71-115 (2009).

33. Halliday, E. \& Gast, R. J. Bacteria in beach sands: An emerging challenge in protecting coastal water quality and bather health. Environ. Sci. Technol. 45(2), 370-379 (2011).

34. Lewenza, S. et al. Pseudomonas aeruginosa displays a dormancy phenotype during long-term survival in water. PLoS ONE 13(9), e0198384 (2018). 
35. Topić, N. et al. Staphylococcus aureus-An additional parameter of bathing water quality for crowded urban beaches. Int. J. Environ. Res. Public Health 18, 5234. https://doi.org/10.3390/ijerph18105234 (2021).

36. Michalska, M., Zorena, K. \& Bartoszewicz, M. Analysis of faecal bacteria isolated from air and seawater samples following an emergency sewage discharge into the Gulf of Gdansk in 2018-Preliminary study. Int. Marit. Health. 70(4), 239-243 (2019).

37. Cunliffe, M. et al. Microbiology of aquatic surface microlayers. FEMS Microbiol. Rev. 35(2), 233-246 (2011).

38. Nakajima, R. et al. Enrichment of microbial abundance in the sea-surface microlayer over a coral reef: Implications for biogeochemical cycles in reef ecosystems. Mar. Ecol. Prog. Ser. 490, 11-22 (2013).

39. Jang, G. I., Hwang, C. Y. \& Cho, B. C. Effects of heavy rainfall on the composition of airborne bacterial communities. Front. Environ. Sci. Eng. 12, 12 (2018).

40. Aydogdu, H., Asan, A. \& Tatman, O. M. Indoor and outdoor airborne bacteria in child day-care centers in Edirne City (Turkey), seasonal distribution and influence of meteorological factors. Environ. Monit. Assess. 164(1-4), 53-66 (2010).

41. Tong, Y. Y. \& Lighthart, B. Solar radiation is shown to select for pigmented bacteria in the ambient outdoor atmosphere. Photochem. Photobiol. 65, 103-106 (1997).

42. Agogué, H. et al. Resistance of marine bacterioneuston to solar radiation. Appl. Environ. Microbiol. 71(9), 5282-5289 (2005).

43. Aller, J. Y., Kuznetsova, M. R., Jahns, C. J. \& Kemp, P. F. The sea surface microlayer as a source of viral and bacterial enrichment in marine aerosols. J. Aerosol Sci. 36(5), 801-812 (2005).

44. Mohr, A. Fate and transport of microorganisms in air. In Manual of Environmental Microbiology (eds Hurst, C. et al.) 961-971 (ASM Press, 2007).

45. Brągoszewska, E. \& Pastuszka, J. S. Influence of meteorological factors on the level and characteristics of culturable bacteria in the air in Gliwice, Upper Silesia (Poland). Aerobiologia 34(2), 241-255 (2018).

46. Michalska, M., Kurpas, M., Zorena, K., Wąż, P. \& Marks, R. Mold and yeast-like fungi in the seaside air of the Gulf of Gdansk (Southern Baltic) after an emergency disposal of raw sewage. J. Fungi 7, 219. https://doi.org/10.3390/jof7030219 (2021).

47. Montero, A., Dueker, M. E. \& O'Mullan, G. D. Culturable bioaerosols along an urban waterfront are primarily associated with coarse particles. PeerJ 4, e2827. https://doi.org/10.7717/peerj.2827 (2016).

48. Marks, R., Kruczalak, K., Jankowska, K. \& Michalska, M. Bacteria and Fungi in Air over the Gulf of Gdańsk and Baltic Sea. J. Aerosol Sci. 32(2), 43-56 (2001).

49. Michalska, M., Bartoszewicz, M., Cieszyńska, M. \& Nowacki, J. Bioaerosols on Tri-city (Gdańsk-Sopot-Gdynia) beaches. Int. Marit. Health 61(1), 41-43 (2010).

50. Michalska, M., Bartoszewicz, M., Cieszyńska, M. \& Nowacki, J. Marine bioaerosol in the area of the Gdańsk Bay. Environ. Med. 14(1), 24-28 (2011).

51. Marks, R., Górecka, E., McCartney, K. \& Borkowski, W. Rising bubbles as mechanism for scavenging and aerosolization of diatoms. J. Aerosol Sci. 128, 79-88 (2019).

52. Marks, R. Bubble rotational features-Preliminary investigations. Oceanography 2(4), 128 (2014).

53. Hu, W. K. et al. Concentration and viability of airborne bacteria over the Kuroshio Extension region in the northwestern Pacific Ocean: Data from three cruises. J. Geophys. Res. Atmos. 122, 12892-12905 (2017).

54. Blanchard, D. C. \& Syzdek, L. D. Mechanism for the water- to air transfer and concentration of bacteria. Science 170, 626-628 (1970).

55. Uetake, J. et al. Seasonal changes of airborne bacterial communities over Tokyo and influence of local meteorology. Front. Microbiol. 10, 1572 (2019).

56. Rahlff, J. et al. High wind speeds prevent formation of a distinct bacterioneuston community in the sea-surface microlayer. FEMS Microbiol. Ecol. https://doi.org/10.1093/femsec/fix041 (2017).

57. Michaud, J. M. et al. Taxon-specific aerosolization of bacteria and viruses in an experimental ocean-atmosphere mesocosm. Nat. Commun. 9, 2017. https://doi.org/10.1038/s41467-018-04409-z (2018).

58. Marks, R. Sub-bubble bi-pirouette splicing of cationic and anionic bases as a process of RNA/DNA creation. Oceanography 3, 135 (2015).

59. Harvey, G. W. Microlayer collection from the sea surface: A new method and initial results. Limnol. Oceanogr. 11, 608-613 (1966).

60. Wurl, O., Wurl, E., Miller, L., Johnson, K. \& Vagle, S. Formation and global distribution of sea-surface microlayers. Biogeosciences 8, 121-135 (2011).

61. Feller, W. An Introduction to Probability Theory and Its Applications Vol. II (Wiley, 1950).

62. PN-89 Z-04111/02. Air purity protection. Microbiological testing. Determination number of bacteria in the atmospheric air (imision) with sampling by aspiration and sedimentation method, 4111 (1989).

63. NIOSH Manual of Analytical Methods (2003-154) - Method Number 0-2000 and the general provisions for EPA-Sampling, Laboratory, and Data Considerations for Microbial Data Collected in the Field. EPA/600/R-18/164 July 2018/www.epa.gov/research.

64. PN-EN ISO 6222:2004. Water Quality-Enumeration of culturable micro-organisms. Colony count by inoculation in a nutrient agar culture medium.

65. APHA. Standard Methods for the Examination of Water and Wastewater (ed. Eaton A.D., Clesceri L.S., Rice E.W., Greenberg A.E) (APHA/AWWA/WEF, 2005).

66. PN-EN ISO 9308-1:2014-12. Water quality. Detection and enumeration of Escherichia coli and coliform bacteria.

67. PN-EN ISO 16266:2009. Water quality. Detection and enumeration of Pseudomonas aeruginosa.

68. NIZP-PZH:ZHK:2007. Presence and number of staphylococci coagulase positive.

69. Regulation of the Minister of Health on the supervision of the quality of bathing water and occasional recreational places (Dz. U. z 2019, poz. 255).

70. Bathing Water Directive (Directive 76/160/EEC 2006). https:/eur-lex.europa.eu/eli/dir/2006/7/oj.

71. Water Law (Journal of Laws of 2018, item 2268, as amended) http://isap.sejm.gov.pl/isap.nsf/DocDetails.xsp?id=WDU2017000 1566.

72. Bezdek, H. F. \& Carlucci, A. F. Surface concentration of marine bacteria. Limnol. Oceanogr. 17, 566-569 (1972).

73. Marks, R. Preliminary investigations on the influence of rain on the production, concentration, and vertical distribution of sea salt aerosol. J. Geophys. Res. 95(C12), 22299-22304 (1990).

74. Friendly, M., Turner, H., Zeileis, A., Murdoch, D. \& Firth D. vcdExtra: "vcd” Extensions and Additions. R Package. Preprint at https://CRAN.R-project.org/package=vcdExtra (2017).

75. Friendly, M. \& Meyer, D. Discrete Data Analysis with R: Visualization and Modeling Techniques for Categorical and Count Data (Taylor \& Francis Group, 2016).

76. A Language and Environment for Statistical Computing R Foundation for Statistical for Statistical Computing. Preprint at https:// www.r-project.org (2018).

\section{Author contributions}

$\mathrm{M}$. $\mathrm{M}$ and $\mathrm{K}$. $\mathrm{Z}$ wrote the main manuscript text together, designed the study, participated in collecting samples and data, and conducted laboratory measurements. R. M. made major corrections and ensured that the calculations of air enrichment with bacteria were correctly carried out. P. W carried out a statistical analysis of the collected data. All authors reviewed and approved the manuscript. 


\section{Funding}

Funding was provided by Medical University of Gdańsk (Grant no. 02-0108 / 07/780).

\section{Competing interests}

The authors declare no competing interests.

\section{Additional information}

Correspondence and requests for materials should be addressed to M.M.

Reprints and permissions information is available at www.nature.com/reprints.

Publisher's note Springer Nature remains neutral with regard to jurisdictional claims in published maps and institutional affiliations.

(c) (i) Open Access This article is licensed under a Creative Commons Attribution 4.0 International License, which permits use, sharing, adaptation, distribution and reproduction in any medium or format, as long as you give appropriate credit to the original author(s) and the source, provide a link to the Creative Commons licence, and indicate if changes were made. The images or other third party material in this article are included in the article's Creative Commons licence, unless indicated otherwise in a credit line to the material. If material is not included in the article's Creative Commons licence and your intended use is not permitted by statutory regulation or exceeds the permitted use, you will need to obtain permission directly from the copyright holder. To view a copy of this licence, visit http://creativecommons.org/licenses/by/4.0/.

(c) The Author(s) 2021 